Bangladesh J. Bot. 42(2): 279-285, 2013 (December)

\title{
EFFECT OF TANNERY WASTEWATER ON THE GROWTH AND YIELD OF SUNFLOWER (HELIANTHUS ANNUUS L.)
}

\author{
Arifa Zereen*, Abdul Wahid ${ }^{1}$, Zaheer-Ud-Din Khan and Andleeb Anwar Sardar \\ Department of Botany, GC University, Lahore, Pakistan
}

Key words: Helianthus annuus, Chromium, Effluents, Pollution

\begin{abstract}
The effects of tanneries wastewater on growth and yield of three cultivars (SF-187, CRN-1435 and DK3915) of sunflower (Helianthus annuus L.) showed that wastewater was not fit for irrigation due to extremely high mineral and heavy metal contents. In addition, effluents were highly alkaline with high load in EC, BOD, COD and SAR values. The amount of iron, manganese, zinc and chromium was also quite high. The growth and yield of plants was adversely affected by effluents treatment, especially at higher doses from seedling stage to maturity leading to reduce biomass and seed production as compared to control. Effluents of tanneries used for irrigation purposes proved to be alarmingly toxic to the growth and yield of the important crop in Kasur region, Pakistan.
\end{abstract}

\section{Introduction}

There are as many as 800 tanneries including small tannin units located in Pakistan. Out of these, 237 units are located in Kasur District (Anonymous 2009). Effluents of tanning industries containing $\mathrm{Cr}$ and other metals are discharged into the local water bodies which are used for irrigation purposes. Presence of chromium beyond the tolerance limit $(<2 \mathrm{ppm})$ makes water unsuitable for crop growth (Sahu et al. 2007). The high level of $\mathrm{Cr}$ and nutrient contents in the effluent has been reported to inhibit the seed germination and seedling growth, which might be due to the presence of excessive amount of dissolved solids, chlorides, sulphides, chromium, high BOD and COD values of the effluent (Mishra and Bera 1995).

Wastewater laden irrigation water affects the plant growth and yield (Barman and Lal 1994) and the accumulation of toxic heavy metals are biomagnified at different trophic levels through food chain (Rai et al. 2002, Saxena et al. 2007, Perez and Sarma 2008). The accumulation, however, depends on the plant species, the elements, its bioavailability, redox, $\mathrm{pH}$, cation exchange capacity, dissolved oxygen, temperature and secretion of roots. Marked toxicity of chromium has been reported with respect to photosynthetic pigments in algae and other higher plants (Nath et al. 2005). Chromium toxicity produces chlorosis and necrosis in plants (Cervantes et al. 2001). The decrease in chlorophyll contents is due to chromium, competing for iron at functional site which might be interfering with the functional metal $\left(\mathrm{Mg}^{2+}\right)$ in the porphyrin ring (Mengel and Kirkby 2001). Chromium exposure results into complete loss of growth in lateral roots while lesser concentration starts damaging root cap, stomata and cotyledonary hair seem to be collapsed and plasma membrane appears to be detached from the cell wall under cytological studies (Mariappan et al. 2001).

The present study was undertaken to investigate the chemical composition of the effluents released by the tanneries and their effects on the growth and yield of three cultivars of sunflower.

*Author for correspondence: <arifazereen@yahoo.com> ${ }^{1}$ Departmernt of Environmental Sciences, Bahauddin Zakariya University, Multan, Pakistan. 


\section{Materials and Methods}

The sunflower (Helianthus annuus L.) cultivars selected for the present study were SF-187, CRN-1435 and DK-3915. The experiment was performed in a wire house at the Botanical Garden, GC University, Lahore during the growing season 2004. Seeds of the cultivars were sown in 126 earthen pots, allocating 42 pots per genotype, having $36 \mathrm{~cm}$ dia. All the pots were filled with 11.5 $\mathrm{kg}$ fine field soil. After germination plants were thinned out and single plant per pot was maintained in five pots while five plants per pot were maintained in two pots for each treatment arranged in a completely randomized design with three replicates.

Effluents from the tanneries were collected prior to any treatment from the Water Treatment Plant Kasur and these were kept under shade. The chemical analysis of the wastewater was carried out in the Environment Department, Govt. of the Punjab, Lahore and Department of Botany, GC University, Lahore. Various dilutions viz., To (control), $\mathrm{T}_{1}(20 \%), \mathrm{T}_{2}(40 \%), \mathrm{T}_{3}(60 \%), \mathrm{T} 4(80 \%)$ and $\mathrm{T}_{5}(100 \%)$ were prepared by mixing appropriate amount of fresh water with polluted water.

Sunflower plants were maintained throughout the growth period according to local agricultural practices. Plants were irrigated after every 4 - 5 days interval. Plant height $(\mathrm{cm})$, number of leaves per plant, number of senescent leaves per plant, diameter of node $(\mathrm{cm})$ and number of flowers per plant were recorded.

In the mid season (March 10, 2004) destructive harvesting was carried out by randomly selecting two pots per treatments (10 plants per treatment) to determine the shoot and root lengths as well as their fresh and dry biomass. At the completion of vegetative growth (during $2^{\text {nd }}$ week of March, 2004) chlorophyll content of selected leaves of different treatments was determined (Arnon 1949). At maturity capitulum diameter, capitulum fresh and dry weight, number of seeds, weight of seeds, 100- seeds weight, straw weight and harvest index were recorded.

The data collected was analyzed statistically using software package costat version 3.03. Analysis of variance and Duncan's Multiple Range Test as described by Steel and Torrie (1996) was carried out at $0.05 \%$ probability.

\section{Results and Discussion}

Analytical data of tanneries wastewater of Kasur city, collected on January, 2004 (Table 1) showed that it belonged to irrigation water quality class $\mathrm{C}_{4}-\mathrm{S}_{4}$ (Soil Survey Bulletin No.14) and is regarded as poor in quality for irrigation point of view. It had nearly all hazardous metals, minerals and constituents in excess amount compared with National Environment Quality Standards (NEQS). The results of tanneries effluent analysis are in accordance with the findings of Tahira (1999). Irrigation waters which has been used successfully for considerable time has electric conductivity less than $2.25 \mathrm{dS} / \mathrm{m}$ and SAR (Sodium Absorption Ratio) values less than 26.

Increasing levels of effluents caused reduction in all the parameters of vegetative growth and biomass in all the cultivars of sunflower i.e., SF-187, CRN-1435 and DK-3915 as compared to control. Moreover, higher effluent concentrations $\left(T_{4}\right.$ and $\left.T_{5}\right)$ delayed seedling emergence a few days and also exhibited marked difference in their morphology and appearance as compared to control. The plants from the control and $\mathrm{T}_{1}$ treatments of all the three sunflower cultivars were healthier and lush green with well developed and expanded leaves as compared to $T_{2}, T_{3}, T_{4}$ and $T_{5}$ treatments. Plants grown in control and $T_{1}$ treatments exhibited vigorous growth as compared to rest of the treatments. Wastewater adversely affected the root and shoot development of all the cultivars of sunflower in higher treatment concentration as compared to counterparts grown in controls $\left(\mathrm{T}_{0}\right)$. Plant length along with fresh and dry weights of shoots and roots indicated that highest effluent treatments caused severe reduction in the weights of all the cultivars of sunflower as compared to control (Table 2). Difference between various treatment means for the plant length, 
were highly significant and ranged from 28 - 31, 24 - 26 and 29 - 33\% for cultivars SF-187, CRN1435 and DK-3915 respectively, compared with control. Similarly fresh shoot and root weight was also reduced corresponding to the gradual increase in the effluent concentrations and ranged from $80-81 \%$ in all the cultivars. Fresh weights of plants from $T_{0}$ treatment were highest followed by successive and statistically significant reduction in plants of other treatments. It can be observed from data that root and shoot dry weights were reduced by 75\% in cultivar SF-187 than that of 85\% in cultivar CRN-1435 and 93\% in cultivar DK-3915 in $\mathrm{T}_{5}$ treated plants when compared with control. A similar trend was also noted in other effluent treatments. The results are in accordance with the findings of Nath et al. (2009) who reported that different concentrations of tannery effluents and $\mathrm{Cr}^{6+}$ showed significant reduction in germination percentage, seedling growth and pigments with increase in concentrations.

Table 1. Physicochemical variables of tanneries wastewater collected from pretreatment plant of Kasur District.

\begin{tabular}{|c|c|c|c|c|c|c|c|}
\hline \multirow[t]{2}{*}{ Variables } & \multicolumn{6}{|c|}{ Treatments (Effluents concentrations) } & \multirow[b]{2}{*}{ NEQS* } \\
\hline & $\begin{array}{c}\mathrm{T}_{0} \\
(0 \%)\end{array}$ & $\begin{array}{c}\mathrm{T}_{1} \\
(20 \%)\end{array}$ & $\begin{array}{c}\mathrm{T}_{2} \\
(40 \%)\end{array}$ & $\begin{array}{c}\mathrm{T}_{3} \\
(60 \%)\end{array}$ & $\begin{array}{c}\mathrm{T}_{4} \\
(80 \%)\end{array}$ & $\begin{array}{c}\mathrm{T}_{5} \\
(100 \%)\end{array}$ & \\
\hline Color & Colorless & Light grey & Light grey & Black grey & Black grey & Black grey & Grey \\
\hline Temp. $\left({ }^{\circ} \mathrm{C}\right)$ & 20 & 20 & 22 & 22 & 23 & 25 & 24 \\
\hline $\mathrm{pH}$ & 7.4 & 7.1 & 6.9 & 7.7 & 8.1 & 8.42 & $6-8.5$ \\
\hline $\mathrm{EC}(\mu \mathrm{S} / \mathrm{cm})$ & 0.75 & 1.8 & 2.5 & 3.0 & 3.6 & 3.5 & 1.5 \\
\hline TSS & 50 & 334 & 757 & 1845 & 2063 & 2150 & 400 \\
\hline TDS & 200 & 712 & 1325 & 4532 & 4352 & 85500 & 2500 \\
\hline BOD & 60 & 257 & 463 & 697 & 868 & 987 & 250 \\
\hline COD & 92 & 454 & 867 & 1514 & 1923 & 2275 & 400 \\
\hline SAR & 9.8 & 18.2 & 25.8 & 32.3 & 39.8 & 45.74 & 10.2 \\
\hline Calcium (meq/l) & 50 & 214 & 332 & 450 & 750 & 900 & 200 \\
\hline Magnesium (meq/l) & 25 & 168 & 285 & 425 & 520 & 625 & 150 \\
\hline Sulphate (meq/l) & 150 & 512 & 1050 & 2280 & 2562 & 3525 & 1000 \\
\hline Sodium (meq/l) & 37 & 57 & 145 & 278 & 364 & 397 & 250 \\
\hline Chloride (meq/l) & 200 & 812 & 1436 & 2032 & 2197 & 2206 & 1000 \\
\hline Copper $\mu \mathrm{g} / \mathrm{g}$ & Nil & Nil & Nil & Nil & Nil & Absent & 1.0 \\
\hline Iron $\mu \mathrm{g} / \mathrm{g}$ & 2.0 & 2.8 & 5.5 & 8.4 & 10.5 & 11.5 & 8.0 \\
\hline Manganese $\mu \mathrm{g} / \mathrm{g}$ & 0.05 & 0.04 & 0.4 & 0.9 & 1.5 & 2.5 & 1.5 \\
\hline Zinc $\mu \mathrm{g} / \mathrm{g}$ & 0.08 & 1.2 & 1.8 & 2.1 & 3.0 & 4.0 & 5.0 \\
\hline Cobolt $\mu \mathrm{g} / \mathrm{g}$ & Nil & Nil & Nil & Nil & Nil & Negligible & 1.0 \\
\hline Lead $\mu \mathrm{g} / \mathrm{g}$ & Nil & Nil & Nil & Nil & Nil & Negligible & 0.5 \\
\hline Nickle $\mu \mathrm{g} / \mathrm{g}$ & Nil & Nil & Nil & Nil & Nil & Negligible & 1.0 \\
\hline Chromium $^{* *} \mu \mathrm{g} / \mathrm{g}$ & Nil & 204 & 750 & 1598 & 1220 & 3550 & 1.0 \\
\hline Hardness & 50 & 215 & 550 & 985 & 1758 & 1924 & 500 \\
\hline
\end{tabular}

*NEQS source: EPA (2007). NEQS: National Environmental Quality Standards for Municipal wastewaters of Pakistan (values in mg/l unless otherwise defined); ${ }^{* *}$ Chromium as both trivalent and hexavalent)

The amount of chlorophyll $a$ was less than chlorophyll $b$ in the plants of all the treatments (Table 2). Percentage reduction in effluents treated plants relative to control was significantly higher and were not much greener and also the senescence started earlier. Table 2 also shows that the amount of chlorophyll (chl. $a$ and $b$ ) was high in plants from $\mathrm{T}_{0}$ and $\mathrm{T}_{1}$ treatments followed by successive statistically significant gradual reduction in plants of increasing effluent levels. The reduction in photosynthetic material in plants grown in high effluent concentrations produced comparatively less productivity than the plants grown in less polluted habitat (Camplin 2001). 
ZEREEN et al.

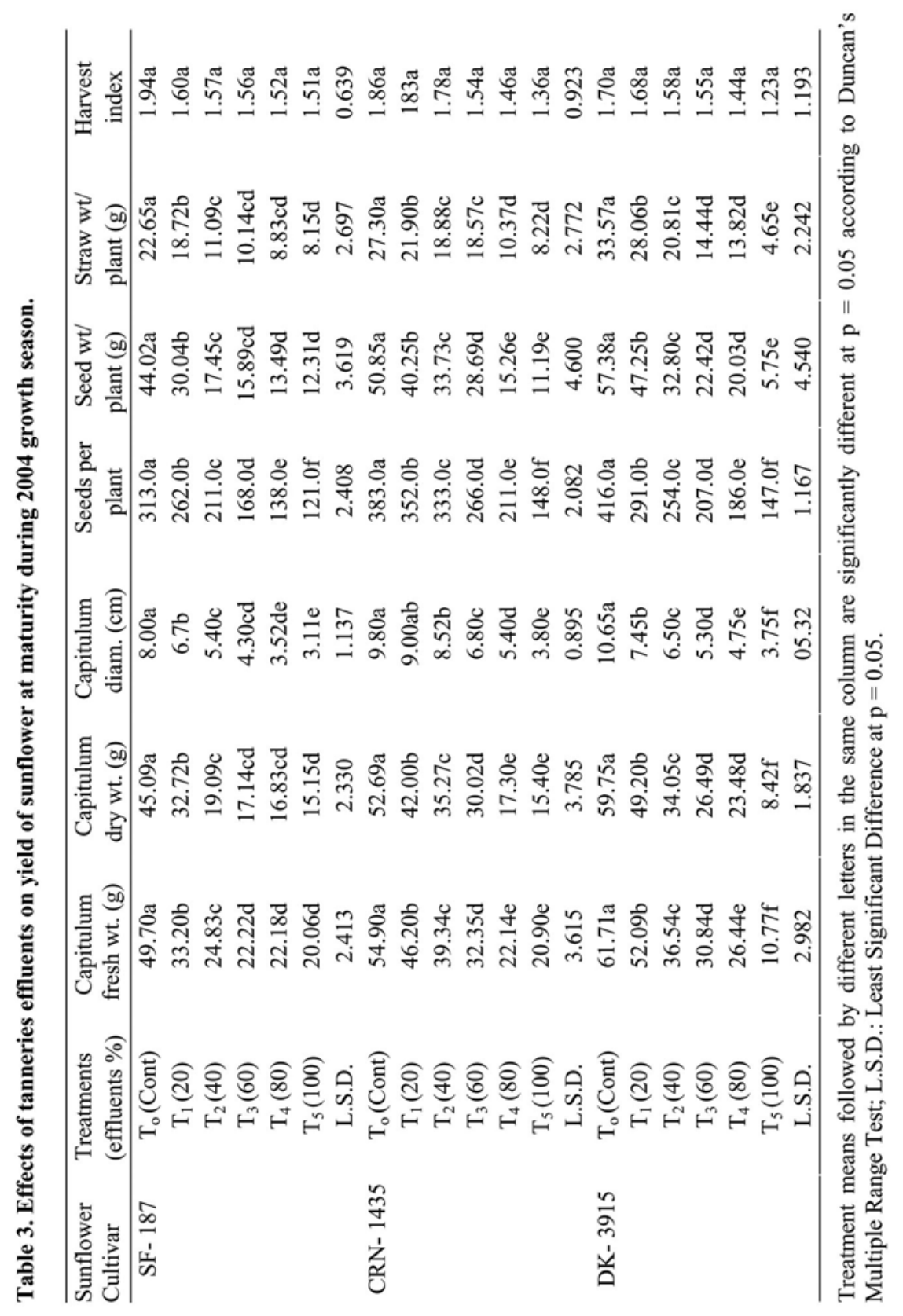


Early senescence in plants treated with high doses along with reduction in other vegetative parameters than that of counterparts plants treated with lower doses in present study is strongly supported by Wahid et al. (2000) and Gilbert and Dubey (2003).

Table 2. Effects of tanneries effluents on yield and biomass of 11week old sunflower cultivars at midseason harvest during 2004 growth season.

\begin{tabular}{|c|c|c|c|c|c|c|c|c|c|}
\hline \multirow[t]{2}{*}{$\begin{array}{l}\text { Sunflower } \\
\text { cultivars }\end{array}$} & \multirow[t]{2}{*}{$\begin{array}{l}\text { Treatments } \\
\text { (Effluents \%) }\end{array}$} & \multicolumn{2}{|c|}{$\begin{array}{l}\text { Plant length } \\
(\mathrm{cm})\end{array}$} & \multicolumn{2}{|c|}{ Fresh weight (g) } & \multicolumn{2}{|c|}{$\begin{array}{l}\text { Dry weight } \\
\text { (g) }\end{array}$} & \multicolumn{2}{|c|}{$\begin{array}{l}\text { Chlorophyll (mg/g } \\
\text { fresh tissue) }\end{array}$} \\
\hline & & Shoot & Root & Shoot & Root & Shoot & Root & $\mathrm{a}$ & $\mathrm{b}$ \\
\hline \multirow[t]{7}{*}{ SF- 187} & $\mathrm{~T}_{\mathrm{o}}$ (Cont) & $109.42 \mathrm{a}$ & $9.27 \mathrm{a}$ & $41.22 \mathrm{a}$ & $3.27 \mathrm{a}$ & 19.53a & $2.05 a$ & $0.027 a$ & $0.033 a$ \\
\hline & $\mathrm{T}_{1}(20)$ & 102.38a & 7.38ab & $22.47 b$ & $2.37 \mathrm{a}$ & $14.80 \mathrm{~b}$ & $1.42 \mathrm{ab}$ & $0.025 b$ & $0.032 \mathrm{a}$ \\
\hline & $\mathrm{T}_{2}(40)$ & $82.10 \mathrm{~b}$ & 6.81ab & $10.47 \mathrm{c}$ & $1.11 \mathrm{~b}$ & $8.75 c$ & $0.73 b c$ & $0.021 c$ & $0.027 b$ \\
\hline & $\mathrm{T}_{3}(60)$ & $79.45 b$ & $6.60 \mathrm{~b}$ & 9.93cd & $0.89 b$ & 8.23.c & $0.66 \mathrm{bc}$ & $0.018 \mathrm{~d}$ & $0.026 b c$ \\
\hline & $\mathrm{T}_{4}(80)$ & $77.58 b$ & $6.49 b$ & $9.80 \mathrm{~cd}$ & $0.85 b$ & $4.89 \mathrm{~d}$ & $0.60 \mathrm{bc}$ & $0.015 \mathrm{e}$ & $0.024 \mathrm{c}$ \\
\hline & $\mathrm{T}_{5}(100)$ & $77.53 b$ & $5.48 b$ & $8.12 \mathrm{~d}$ & $0.79 b$ & $4.89 d$ & $0.42 c$ & $0.011 \mathrm{f}$ & $0.021 d$ \\
\hline & L.S.D. & 12.607 & 2.475 & 1.997 & 0.941 & 2.662 & 0.819 & 0.002 & 0.002 \\
\hline \multirow[t]{7}{*}{ CRN- 1435} & $\mathrm{~T}_{\mathrm{o}}$ (Cont) & 126.26a & 12.16a & $35.30 a$ & 18.19a & $19.77 a$ & $5.69 a$ & $0.034 a$ & $0.047 a$ \\
\hline & $\mathrm{T}_{1}(20)$ & $123.41 b$ & $9.20 \mathrm{~b}$ & $23.42 b$ & $3.53 \mathrm{~b}$ & 17.95ab & $2.20 \mathrm{~b}$ & $0.026 b$ & $0.042 b$ \\
\hline & $\mathrm{T}_{2}(40)$ & $115.42 \mathrm{c}$ & $9.08 \mathrm{~b}$ & $20.39 c$ & $3.37 \mathrm{~b}$ & 15.60b & $1.74 \mathrm{bc}$ & $0.024 \mathrm{c}$ & $0.039 \mathrm{c}$ \\
\hline & $\mathrm{T}_{3}(60)$ & $107.32 d$ & $7.99 c$ & $18.50 \mathrm{~d}$ & $2.50 \mathrm{bc}$ & $15.51 \mathrm{~b}$ & $1.73 b c$ & $0.021 \mathrm{~d}$ & $0.038 \mathrm{c}$ \\
\hline & $\mathrm{T}_{4}(80)$ & $96.16 \mathrm{e}$ & $7.18 \mathrm{e}$ & $11.46 \mathrm{e}$ & $1.72 \mathrm{c}$ & $6.93 c$ & $1.43 \mathrm{bc}$ & $0.017 \mathrm{e}$ & $0.035 \mathrm{~d}$ \\
\hline & $\mathrm{T}_{5}(100)$ & $95.06 \mathrm{e}$ & $7.16 \mathrm{c}$ & $10.86 \mathrm{e}$ & $1.56 \mathrm{c}$ & $3.40 \mathrm{~d}$ & $0.61 \mathrm{e}$ & $0.014 \mathrm{f}$ & $0.030 \mathrm{e}$ \\
\hline & L.S.D. & 1.530 & 1.014 & 1.560 & 1.385 & 2.618 & 1.277 & 0.002 & 0.002 \\
\hline \multirow[t]{7}{*}{ DK- 3915} & $\mathrm{~T}_{\mathrm{o}}$ (Cont) & 126.78a & $8.81 \mathrm{a}$ & $50.59 a$ & 10.39a & 29.36a & $1.84 \mathrm{a}$ & $0.038 \mathrm{a}$ & $0.050 \mathrm{a}$ \\
\hline & $\mathrm{T}_{1}(20)$ & 109.46ab & $8.07 a$ & $45.21 b$ & $8.35 b$ & $25.10 \mathrm{~b}$ & $1.00 \mathrm{ab}$ & $0.030 \mathrm{~b}$ & $0.046 \mathrm{~b}$ \\
\hline & $\mathrm{T}_{2}(40)$ & $96.40 \mathrm{~b}$ & $7.02 \mathrm{a}$ & $39.99 c$ & 7.30c & $18.57 \mathrm{c}$ & 0.99ab & $0.024 \mathrm{c}$ & $0.038 \mathrm{c}$ \\
\hline & $\mathrm{T}_{3}(60)$ & $95.82 \mathrm{~b}$ & $6.96 a$ & $30.29 d$ & $6.02 \mathrm{~d}$ & $9.56 \mathrm{~d}$ & $0.81 b$ & $0.021 \mathrm{~d}$ & $0.035 \mathrm{~d}$ \\
\hline & $\mathrm{T}_{4}(80)$ & $89.00 \mathrm{~b}$ & $6.80 \mathrm{a}$ & $25.08 \mathrm{e}$ & $5.51 \mathrm{e}$ & $9.56 \mathrm{~d}$ & $0.81 b$ & 0.019e & $0.034 d$ \\
\hline & $\mathrm{T}_{5}(100)$ & $88.06 \mathrm{~b}$ & $6.31 \mathrm{a}$ & $15.04 \mathrm{f}$ & $3.38 \mathrm{f}$ & $1.43 e$ & $0.55 b$ & $0.017 \mathrm{e}$ & $0.031 \mathrm{e}$ \\
\hline & L.S.D. & 20.619 & 2.949 & 0.650 & 0.750 & 2.467 & 0.940 & 0.002 & 0.002 \\
\hline
\end{tabular}

Treatment means followed by different letters in the same column are significantly different at $\mathrm{p}=0.05$ according to Duncan's Multiple Range Test; L.S.D.: Least Significant Difference at $p=0.05$.

At final harvest, the growth was also higher in control and as the pollutant treatment successively increased the growth of plants was gradually reduced (Table 3). All the parameters of reproductive growth decreased significantly from $T_{2}$ to higher effluent concentrations i.e., $T_{4}$ and $\mathrm{T}_{5}$ in all the cultivars of sunflower. Capitulum diameter was greater in control plants in all the cultivars and exhibited gradual decrease with corresponding increase in effluent treatments. The magnitude of reduction in capitulum diameter in $\mathrm{T}_{5}$ for cv. DK-3915 remained higher (86\%) as compared to cv. SF-187 (64\%) and cv. CRN-1435 (70\%), depicting that DK- 3915 cultivar is more sensitive. Seed production was higher in control (To) plants while gradual significant loss in seeds number was observed in all the effluent treated plants. The reduction in seed number of $T_{5}$ treated plants in cultivar SF-187 was 61\% while it was 62\% in CRN-1435 and 65\% in DK-3915 depicting its greater sensitivity to seed production. Plants treated with $T_{4}$ and $T_{5}$ were extremely stunted, so they produced fewer light weight seeds. Percentage differences recorded were highly different and statistically significant in higher pollution levels. Seed weight was also higher in $\mathrm{T}_{0}$ 
and $\mathrm{T}_{1}$ treatments as compared to seeds produced in $\mathrm{T}_{4}$ and $\mathrm{T}_{5}$ treatments. The magnitude of reduction in seed weight per plant in $\mathrm{T}_{5}$ compared to control was $72 \%$ in cultivars SF-187, while it was a bit higher in cultivar CRN-1435 (78\%) and DK-3915 (90\%) exhibiting drastic affect on seed production and seed weight of sunflower cultivars. 100- seed weight was also gradually reduced in higher pollution levels. Harvest index was higher in plants collected from control and $T_{1}$ treatments when compared with that of higher effluents treatments. The magnitude of reduction was higher in cv. DK-3915 (27\%) as compared to cv. SF-187(23\%) and cv. CRN-1435 (22\%). The results are in line with Gillbert and Dubey (2003) who reported that biomass reduction by effluents in first step results in severe yield reduction at latter stages of growth.

So, high concentrations of effluents (80 - 100\%), proved deleterious to plant growth, both at vegetative and reproductive stages. Effluents treatment especially at higher concentrations along with the increased EC values of treated soil suggested that treatment with higher effluent concentrations induced some kind of stress on plants (salinity stress), which affected various metabolic processes resulting in reduction of vegetative and later on reproductive growth of the plant. Hewitt and Keller (2003) reported injurious effects of wastewater of a chemical manufacturing plant on the growth of maize, soybean and wheat. Similar views were also reported by other investigators (Kilicel and Dag 2006, Yasir 2003, Rusan et al. 2007).

However, diluted effluents may be used for the crop. Significant growth and yield losses due to tannery effluents is a matter of serious concern from view point of agriculture as Pakistan is an agrarian country and its soils are being contaminated with toxic loads of industries.

\section{References}

Anonymous 2009. Leather Directory. Leather industry development, Ministry of Industry, Govt. of Pakistan, Islamabad.

Arnon DT 1949. Copper enzymes in isolated chloroplast: polyphenol oxidase in Beta vulgaris. Pl. Physiol. 24: 1 - 15.

Barman SC and Lal MM 1994. Accumulation of heavy metals (Zn, Cu, Cd and $\mathrm{Pb}$ ) in soil and cultivated vegetables and weeds grown in industrially polluted fields. J. Environ. Biol. 15: 107-115.

Camplin WC 2001. Effects of paper and pulp factory of Indonesia on the growth and yield potential of cereal crops. Environ. Pollu. 33(13): 324-331.

Cervantes C, Campos-Garcia J, Debars S, Gutierrez-Corona F, Loza-Tavera H, Carlos-Tarres-Guzman M and Moreno-Sanchez R 2001. Interaction of chromium with microgenesis and plants. FEMS Microbiol. Rev. 25: 335-347.

Gilbert M and Dubey R 2003. Biochemical studies using barley and oat grown in effluent treated fields. J. Agronomy. 2(2): 115- 121.

Hewitt F and Keller T 2003. Water pollution impact on bean and cereals. J. Agronomy. 11(3): 175- 185.

Kilicel F and Dag B 2006. The relationship between some heavy metal concentrations in soil, leaves and fruits of starling delicious (Malus communis Lam.). Turk. Review. Analy. Chem., 25(4): 271- 283.

Mariappan V, Balamurugan T and Rajan MR 2001. Irrigational utilization of treated tannery effluent and its impact on growth and some biochemical characteristics of certain crop plants. Ecol. Environ. Cons. 7: 205-210.

Mengel K and Kirkby EA 2001. Element with more toxic effect. In: Principle of plant nutrition. Kluwer Academic Publisher, London, pp. 656-670.

Mishra P and Bera AK 1995. Effect of tannery effluent on seed germination and early seedling growth in wheat. Seed Res. 23: 129-131.

Nath K, Kamlesh, Saini S and Sharma YK 2005. Chromium in tannery industry effluent and its effect on plant metabolism and growth. J. Environ. Biol. 26: 197-204. 
Nath K, Singh D, Shyam S and Sharma YK 2009. Phytotoxic effects of chromium and tannery effluents on growth and metabolism of Phaseolus mungo Roxb. J. Environ. Biol. 30(2): 227-234.

Perez TR and Sarma SSS 2008. Combined effects of heavy metal (Hg) concentration and algal (Chlorella vulgaris) food density on the population growth of Brachionus calyciflorus (Rotifera: Brachionidae). J. Environ. Biol. 29: 139-142.

Rai UN, Tripathi RD and Kumar N 2002. Bioaccumulation of chromium and toxicity on growth, photosynthetic pigments, photosynthesis, in vivo nitrate reductase activity and protein content in chlorococcalear green alga, Glaucocystis nostochinearum ltzigsohn. Chromosphere. 25: 721-732.

Rusan H, Kamre L and Manser T 2007. Wastewater irrigation impacts on crops with respect to heavy metals. Crop Sci. 5: 114-118.

Sahu RK, Katiyar S, Tiwari J and Kisku GC 2007. Assessment of drain water receiving effluent from tanneries and its impact on soil and plants with particular emphasis on bioaccumulation of heavy metals. J. Environ. Biol. 28: 685-690.

Saxena R, Shalini, Upreti DK and Sharma N 2007. Heavy metal accumulation in lichens growing in north side of Lucknow city, India. J. Environ.Biol. 28: 49-51.

Steel RGD and Torrie VJH 1996. Principles and procedures of statistics. McGraw-Hill, New York.

Tahira SA 1999. Effect of tannery effluents on some morpho- chemical aspects of mustard. Implication for Phytoremediation. M.Phil. (Botany) Thesis submitted to University of Agricultural, Faisalabad.

Wahid A, Nasir MGA and Ahmad SS 2000. Effects of water pollution on growth and yield of soybean. Acta. Scient. 10: 51-58.

Yasir M 2003. Wastewater and its effects on some crops. Water \& soil Pollut. 2: 32-36. 